laws, it so overlooks also the established principle of our juris prudence, that the thought of a man, undereloped in act, is not to bind him" (2 Bishop, § 47 ; 1 Bishop Crim. Law, § 312), "as to create doubt whether it would be adopted, after consideration. by any court."

E. R. R. ,

\title{
HOW FAR ARE EXPRESS COMPANIES LIABLE?
}

A WRITER in the June number of the Register, 1866, has called the attention of the profession, in a clear and well-writter article, to the nature and extent of the liabilities of express com panies as common carriers. It is not to add force or cogency to the views of this writer, so far as he has carried them, but to suggest that he does not carry them far enough, that the following thoughts are offered for consideration. The subject, in view of the magnitude and extent of the express business of the country, is obviously one of no ordinary interest.

The question is, whether to companies organized as these are, and doing their business through the instrumentality of other companies, upon whom they are dependent for the means of transporting the goods committed to their charge from place to place, the same rigid and stringent rules are to be applied as were found necessary in a half-barbarous age, when the only avenues of tran- . sit were beset by highwaymen, and the traveller found but a questionable security within such hostelries as the country afforded, A marked distinction between the condition of a carrier then and now is indicated by the terms of the question itself. Saying nothing of the comparatively trifling value or amount of money or merchandise to be transported at that day, in contrast with the present, the ordinary means by which the business was carried on, enabled the carrier to exercise a personal care and oversight of whatever was committed to his charge, either by being himself the driver of his own wagon or the master of his own water-craft; or selecting for his servants such persons as he was satisfied were safe to be trusted. Whereas, as now conducted, the expressman is obliged to make use of such accommodation as the railway or steamboat companies provide for him, over which he can exercise no control, and for whose want of care or skill he can be, in no way, morally respon sible. Carrying was always a matter of agency, a something 
to be done for an employer, the owner of the article to be carried. And the main difference between this agency, as formerly managed and now, consisted in this: that the carrier then undertook a work which he could do by himself or servants of his orn selection, but now is obliged to depend for a part of the rork upon other agencies over which he has no control. If he assumed the risk of a carrier-to guard against all acts but those of Providence or a public enemy - he had only to exercise care proportioned to the risk, for which he was at liberty to charge, and was not subjected to the hazard of casualties happening by a force as much beyond his control as that of the winds or the earthquake. The change, moreover, in this respect is perfectly well understnod by every one who has occasion to employ an express. He knows that in carrying a package of money or parcel of goods from New York to Chicago the expressman must encounter the hazard of a force as irresistible as that of a' public enemy, and that no foresight or care of his can counteract this when brought to bear upon him or the property in his charge. It is the public who create these companies, to whom is confided the trust of supplying the means by which the expressman alone can execute his charge. And so far as he is concerned, it matters not whether he is obstructed by an accident which results from the carelessness of an engineer, or the sudden weakening of a culvert by a flood, without the company's fault, or the destruction of a bridge by fire. And if for the loss or damage to goods thus occasioned the expressman is liable, is it not, in fact, adding to the original stringency of a carrier's liability a new and more formidable class of hazards?

The writer referred to maintains with great force and propriety that he may protect himself from them by the terms of his agreement of bailment. But it is worthy of inquiry whether, upon principle, the law itself does not limit his liability for any accident occasioned by the act of the company whose agents he is obliged to employ. If the question may be regarded as an open one, is there not a solution of it in the familiar law of agency? Since the doctrine of Bush v. Steinman, 1 B. \& P. 404, has given place to a more rational view of the relation of employers and their employees to third persons (4 Exch. 251, 3 Gray 349) it seems to be a settled rule of law that if I have occasion to employ another to perform a job of work which subdivides itself into 
separate departments, and he employs a master workman to do what is requisite as to one of these, neither I nor my immediate employee is liable for the consequences of a want of skill or care of one of the workmen employed by such sub-contractor. Each contractor for the separate parts of the work is responsible for his orn act and that of his servants, though in the employ, in one sense, of one general contractor or employer. The inquiry in such cases is, whose was the servant by whose carelessness the injury mas occasioned? And it is to his master that the injured party, if a stranger, is to look: Quarman v. Burnett, $6 \mathrm{M}$. \& W. 499; Millegan v. Wedge, 12 A. \& E. 737 ; Rapson v. Cubitt, 9 M. \& W. 709 ; Hilliard v. Richard8on, 3 Gray 349 ; Linton

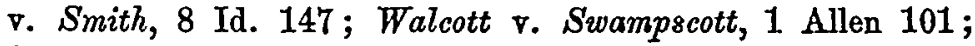
Reeder v. N. W. Railway, 4 Exch. 244.

This does not, of course, include acts of robbery or peculation Where applied to the business of carriers, since it is the policy of the law to discountenance all possible combinations between carriers and third persons to the injury of those who employ them. But if I engage to take charge of and carry as an expressman, a valuable package, a costly jar, or a basket of choice wines, for instance, from Philadelphia to St. Louis, and my employer knows that in order to do it I must employ some two or three successive railroad companies to carry me together with the package, and on my way thither it is broken or destroyed by the carelessness of some engineer or switch-tender or by a defective rail or a broken car-wheel, why should not the principle above stated be applied, and the railroad company which occasions the loss be accountable in the first place to the orner, and not I? It would seem to be more in accordance with the rules applicable to other departments of business. It does not violate the principal respondeat superior, for, in the case supposed, I am in no sense a superior. I an myself as passive as the package that sits by my side or is carried in the same train that $I$ am. And the owner of the package knew when he intrusted me with it, not only that I might, but that I must, employ the very railroad company which I did, and that the work of transportation upon the road was to be done by them and not by me. .

But what was only intended to be a suggestion in view of remarks of the writer referred to, has grown to something like a discussion of a subject which, to do full justice to it, would 